\title{
Imidacloprid Concentrations in Green Ash (Fraxinus pennsylvanica) Following Treatments with Two Trunk-Injection Methods
}

\author{
Mark Harrell
}

\begin{abstract}
Two imidacloprid trunk-injection products (Pointer ${ }^{\mathrm{TM}}$ and Imicide ${ }^{\circledR}$ ) were applied to green ash (Fraxinus pennsylvanica Marsh.) in May and July to compare the concentrations of imidacloprid in sap and leaf and trunk tissues after the injections. Sap samples were extracted from shoots 0, 3, 7, 30, 60, and 90 days after treatment and analyzed for imidacloprid. Dry leaf samples were analyzed for imidacloprid at 30 and 90 days after treatment. Combined xylem and

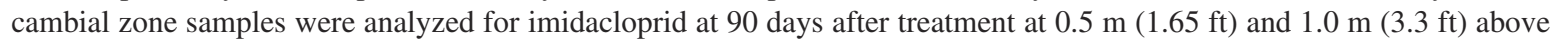
the injection sites. Sap imidacloprid concentrations in trees treated in May with Pointer were significantly higher than the untreated control at 7 days after treatment $(P<0.05)$ but were not significantly different from the control on other days or different from Imicide on any day. Sap imidacloprid levels in trees treated in July with Pointer were significantly higher than the control at 30 days after treatment but were not significantly different from Imicide. Dry leaf imidacloprid levels in trees treated with Pointer were significantly higher than the Imicide and control treatments at 30 and 90 days after treatment. Xylem and cambial zone imidacloprid levels in trees treated with Pointer were significant higher than the Imicide

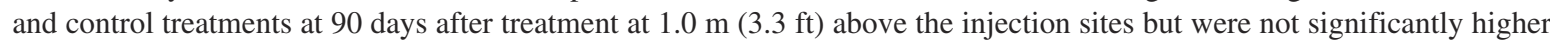
at $0.5 \mathrm{~m}(1.65 \mathrm{ft})$. No imidacloprid levels from Imicide were significantly different from those in the untreated control trees.

Key Words. Agrilus planipennis; ash; emerald ash borer; Fraxinus pennsylvanica; Imicide ${ }^{\circledR}$; imidacloprid; injection; insecticide; Pointer ${ }^{\mathrm{TM}}$; trunk.
\end{abstract}

Trunk injections are one of the new tools available to arborists to control a variety of insect pests and diseases. Most injection treatments compared to other methods have the advantages of using much lower volumes of material, requiring simpler equipment, and placing the chemical inside the tree, where it targets the pest or disease and is much less likely to be a problem for people, wildlife, beneficial insects, and other nontarget organisms.

Imidacloprid is one trunk-injectable insecticide that has been found to be effective in controlling a number of borers and sucking insect pests of trees (Gill et al. 1999; Young 2002; McCullough et al. 2004; Doccola et al. 2005). Imidacloprid trunk injections have been a major component of the eradication efforts for the Asian longhorned beetle in New York and Illinois, U.S. (USDA 2000) and are among the recommended treatments for the emerald ash borer in Michigan (Smitley 2005).

One of the studies conducted to test the effectiveness of imidacloprid trunk-injection treatments against the emerald ash borer suggested that Pointer ${ }^{\mathrm{TM}}$ insecticide (ArborSystems, Omaha, NE) was not effective in controlling this pest (McCullough et al. 2004). Another report, however, described ash in Plymouth, Michigan, recovering from the emerald ash borer following treatments with Pointer, and suggested that Pointer is effective (Roberts 2004). The current study was conducted to re-examine Pointer for its potential to control borers such as the emerald ash borer by comparing the concentrations of imidacloprid from Pointer in sap and tree tissues with those from Imicide ${ }^{\circledR}$ (J.J. Mauget Co., Arcadia, $\mathrm{CA}$ ), a product commonly used for borer control.

\section{MATERIALS AND METHODS}

Green ash (Fraxinus pennsylvanica Marsh.) trees at two sites in eastern Nebraska, were trunk injected with either Pointer (5\% active ingredient [a.i.] at $1 \mathrm{~mL} / 15 \mathrm{~cm}$ [6 in] intervals around the trunk circumference) or Imicide (10\% a.i. at 3 $\mathrm{mL} / 15 \mathrm{~cm}$ [6 in] intervals around the trunk circumference) following label instructions and using label rates. Sap and tissue samples were analyzed for imidacloprid at some or all of the intervals: $0,3,7,30,60$, and 90 days after treatment using QuantiPlate ${ }^{\mathrm{TM}}$ (ELISA) kits for imidacloprid (EnviroLogix, Portland, ME).

Treatments were applied on 4 May 2004, at site 1 and on 12 July 2004, at site 2 . Trees at site 1 ranged in trunk diameter from 14 to $24 \mathrm{~cm}$ (5.6 to $9.6 \mathrm{in}$ ) and were approximately $7 \mathrm{~m}$ $(23 \mathrm{ft})$ tall. Trees at site 2 ranged in diameter from 12 to 18 $\mathrm{cm}$ (4.8 to $7.2 \mathrm{in}$ ) and had an average height of approximately $6 \mathrm{~m}(20 \mathrm{ft})$. Trees were blocked by size and location, and treatments were applied randomly to trees within blocks. Each treatment and an untreated control were replicated three 
times at each site. Weather conditions on 4 May were clear sky, $13 \mathrm{kph}(8 \mathrm{mph})$ average wind speed, and average daytime temperature of $22^{\circ} \mathrm{C}\left(71^{\circ} \mathrm{F}\right)$ (based on averages from the two closest weather stations, Lincoln and Omaha, Nebraska). Conditions on 12 July were clear sky, $16 \mathrm{kph}(10 \mathrm{mph})$ average wind speed, and average daytime temperature of $28^{\circ} \mathrm{C}$ $\left(82^{\circ} \mathrm{F}\right)$. In the month after the 4 May treatments, rainfall was $142 \mathrm{~mm}$ (5.68 in) and the average maximum temperature was $23^{\circ} \mathrm{C}\left(73^{\circ} \mathrm{F}\right)$. In the month after the 12 July treatments, rainfall was $113 \mathrm{~mm}$ (4.52 in) and the average maximum temperature was $29^{\circ} \mathrm{C}\left(84^{\circ} \mathrm{F}\right)$. No supplemental irrigation was provided.

Sap and leaf samples were taken from three widely separated branches in the outer middle crown on each tree on each sampling date. Sap samples were collected from the freshly cut shoots using a pressure chamber (PMS Instrument Co., Albany, OR). Leaf samples were taken from the same shoots used for the sap samples. Three combined xylem and cambial zone samples were taken from the trunk of each tree at 0.5 and $1.0 \mathrm{~m}(1.65$ and $3.3 \mathrm{ft})$ above the average height of the injection sites, or at similar heights on the untreated trees, by drilling through the bark and outer layers of wood with a 10 $\mathrm{cm}$ (4 in) diameter bit, discarding the bark and phloem tissues, and keeping the cambial zone and xylem tissue to a depth just beyond the third annual ring. The samples at each height were approximately evenly spaced around the trunk and were taken without regard to the locations around the circumference where the injections had been made.

Leaf samples and xylem and cambial zone samples were air dried and were extracted with methanol before analysis. Sample-collection equipment was cleaned between each sample to avoid cross-contamination. All samples were analyzed twice by the ELISA test. Data were analyzed by analysis of variance and means were separated with the Tukey HSD test after correcting for false-positive background values. Means were considered different at the 0.05 level of significance.

\section{RESULTS}

Sap imidacloprid concentrations in trees treated in May with Pointer were significantly higher than the control 7 days after treatment (Figure 1, $P<0.05$, Tukey HSD test), but after day 7 no treatment was significantly different from the control or the other treatment. Sap imidacloprid concentrations in trees treated in July with Pointer were significantly higher than the control 30 days after treatment (Figure 2) but were not significantly different from Imicide.

Dry leaf imidacloprid concentrations in trees treated with Pointer were significantly higher than those in Imicidetreated and control trees at 30 days and 90 days after treatment (Figure 3). The concentration of imidacloprid from Pointer in xylem and cambial zone tissue 90 days after treatment was significantly higher than the concentrations from

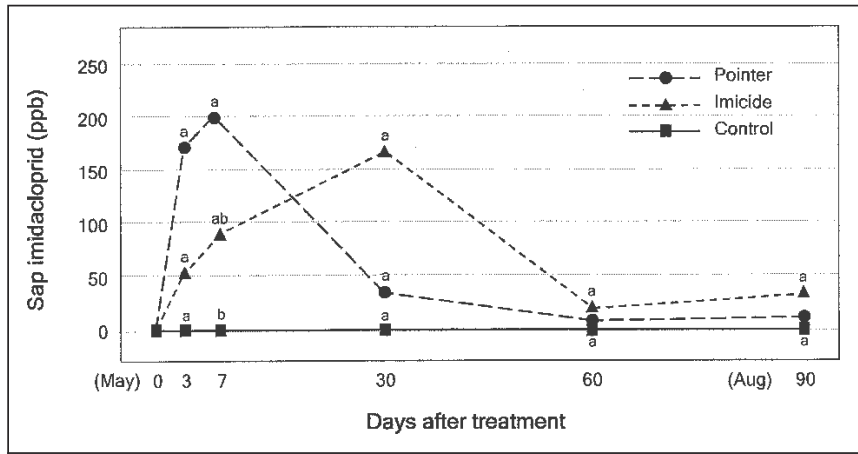

Figure 1. Imidacloprid concentration in sap of green ash (Fraxinus pennsylvanica) treated in May. Values on the same day followed by different letters are significantly different from each other ( $P<0.05$, Tukey HSD test).

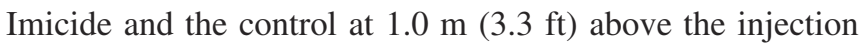
sites (Pointer, $55 \mathrm{ppb}$; Imicide, $0 \mathrm{ppb}$; control, $0 \mathrm{ppb} ; P<$ 0.05 , Tukey HSD test) but not at $0.5 \mathrm{~m}(1.65 \mathrm{ft})$ above the injection sites (Pointer, $10 \mathrm{ppb}$; Imicide, $0 \mathrm{ppb}$; control, 0 ppb; $P>0.05)$.

\section{DISCUSSION}

Pointer injections produced imidacloprid concentrations in sap, leaves, and xylem and cambial zone tissues that were at least as high as those provided by Imicide, a product commonly used for borer control. The results from the sap and xylem and cambial zone tissues suggest that Pointer would be at least as effective as Imicide in providing protection against borers that feed at the phloem and xylem interface. This conclusion is supported by the success in protecting trees in

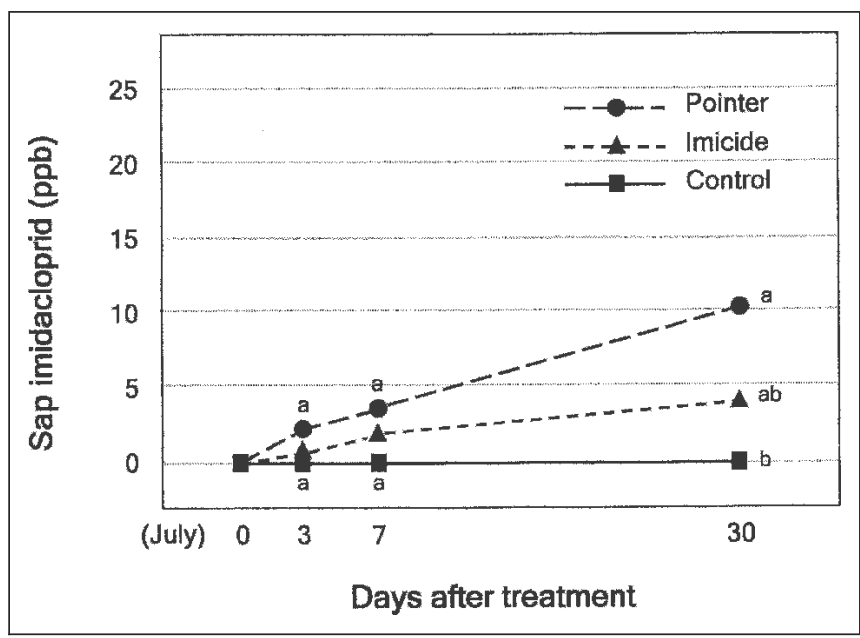

Figure 2. Imidacloprid concentration in sap of green ash (Fraxinus pennsylvanica) treated in July. Values on the same day followed by different letters are significantly different from each other $(P<0.05$, Tukey HSD test). 


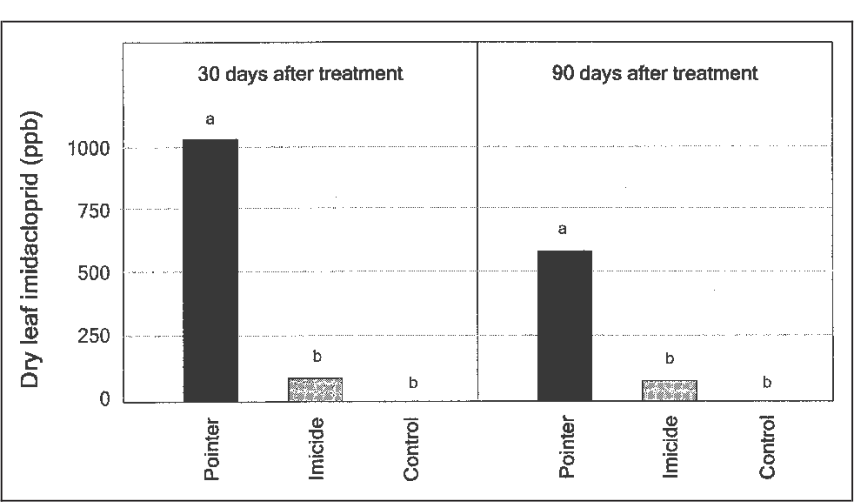

Figure 3. Imidacloprid concentration in dry leaf tissue of green ash (Fraxinus pennsylvanica) treated in May and measured 30 and 90 days after treatment. Values on the same day followed by different letters are significantly different from each other $(P<0.05$, Tukey HSD test).

Plymouth, Michigan, with Pointer against the emerald ash borer (Roberts 2004).

Imidacloprid concentrations in dry leaf samples reflect the accumulated imidacloprid that moved previously in the sap. The higher concentration of imidacloprid found in xylem and cambial zone tissue of trees treated with Pointer suggests that either imidacloprid from Pointer is able to remain longer in the trunk after the injection or the chemical is dispersed more broadly in the tissues and was therefore more likely to be picked up by the sampling. The higher concentrations of imidacloprid measured in trees treated in May compared to those treated in July (Figure 2) are presumably because of a higher amount of sap flowing through the xylem earlier in the season that carried the injected material to other parts of the tree more quickly.

\section{CONCLUSIONS}

The results suggest that Pointer is as effective as Imicide in delivering imidacloprid to sap, leaves, and outer xylem and cambial zone tissues. This supports the conclusion reached by Roberts (2004) that Pointer can be an effective product for borer control. This study compares the concentrations of imidacloprid in sap and leaf and trunk tissues after injections with Pointer and Imicide. An understanding of how trunkinjected imidacloprid moves in trees and is deposited in tissues will help arborists more effectively control borers and other tree pests.

\section{LITERATURE CITED}

Doccola, J.J., I. Ramasamy, P. Castillo, et al. 2005. Erratum: Efficacy of Arborjet Viper microinjections in the management of hemlock woolly adelgid (Adelges tsugae). Journal of Arboriculture 31:203-206.

Gill, S., D.K. Jefferson, R.M. Reeser, and M.J. Raupp. 1999. Use of soil and trunk injection of systemic insecticides to control lace bug on hawthorn. Journal of Arboriculture 25:38-42.

McCullough, D.G., D.R. Smitley, and T. Poland. 2004. Evaluation of insecticides to control emerald ash borer adults and larvae. www.emeraldashborer.info/files/ bulletin.pdf (accessed 3/9/06).

Roberts, D.L. 2004. MSU's 2003 EAB research results: Some interpretations and recommendations. The Landsculptor, February, pp. 21-23.

Smitley, D. 2005. Professional guide to emerald ash borer treatments. www.emeraldashborer.info/files/Professional EABGuide.pdf (accessed 3/9/06).

USDA. 2000. New pest response guidelines: Asian longhorned beetle Anoplophora glabripennis. USDA APHIS PPQ, www.aphis.usda.gov/ppq/ep/alb/rguidelines42800. pdf (accessed 3/9/06).

Young, L.C. 2002. The efficacy of micro-injected imidacloprid and oxydemeton-methyl on red gum eucalyptus trees (Eucalyptus camaldulensis) infested with red gum lerp psyllid (Glycaspis brimblecombei). Journal of Arboriculture 28:144-147.

\section{Mark Harrell \\ Forest Health Program Leader \\ Nebraska Forest Service \\ University of Nebraska \\ Lincoln, NE 68583-0815, U.S. \\ mharrell1@unl.edu}

Résumé. Deux injections dans le tronc de produits contenant de l'imidacloprid (Pointer ${ }^{\mathrm{TM}}$ de ArborSystems, et Imicide ${ }^{\circledR}$ de J.J. Mauget Co.) ont été faites sur des frênes de Pennsylvanie (Fraxinus pennsylvanica Marsh.) en mai et juillet afin de comparer les concentrations en imidacloprid dans la sève ainsi que dans les tissus foliaires et ceux du tronc suivant les injections. Des échantillons de sève ont été extraits à partir des pousses $0,3,7,30$, 60 et 90 jours après le traitement pour être analysés en regard de l'imidacloprid. Des échantillons de feuilles sèches ont été analysés en regard du même produit 30 et 90 jours après le traitement. Des échantillons combinés dans la zone du cambium et du xylème recueillis à 0,5 et $1 \mathrm{~m}$ au-dessus de la zone d'injection ont été analysés en regard du même produit 90 jours après le traitement. Les concentrations d'imidacloprid dans la sève des arbres traités en mai avec le Pointer étaient significativement plus élevées que celles chez les arbres du groupe-témoin 7 jours après le traitement $(P<0,05)$, mais n'étaient significativement pas différentes par rapport à celles du groupe des arbres-témoins lors des autres périodes d'analyse; de plus ces mêmes concentrations n'étaient pas différentes de celles de l'Imicide, et ce à n'importe quelle période d'analyse. Les niveaux d'imidacloprid dans la sève des arbres traités en juillet avec le Pointer étaient significativement plus élevés que chez les arbres du groupe-témoin 30 jours après le traitement, mais n'étaient significativement pas différents de ceux traités avec l'Imicide. Les niveaux 
d'imidacloprid dans les feuilles sèches des arbres traités avec le Pointer étaient significativement plus élevés que ceux avec l'Imicide et ceux du groupe-témoin, et ce 30 et 90 jours après le traitement. Les niveaux d'imidacloprid dans la zone du cambium et du xylème prélevée à $1 \mathrm{~m}$ au-dessus de l'injection chez les arbres traités avec le Pointer étaient significativement plus élevés que ceux avec l'Imicide ou ceux du groupe-témoin, et ce 90 jours après le traitement; par contre, il n'y avait aucune différence significativement plus élevée à $0,5 \mathrm{~m}$ au-dessus de la zone d'injection. Aucun niveau d'Imicide s'est avéré être significativement différent de ceux retrouvés chez les arbres du groupe-témoin.

Zusammenfassung. In Mai und Juli wurden an Grüner Esche (Fraxinus pennsylvanica Marsh.) 2 Stamm-Injektions-Produkte ausprobiert, um die Konzentrationen von Imidacloprid im Saft und Blatt und Zellsäften im Stamm nach der Injektion zu vergleichen. Von den Trieben wurden 0, 3, 7, 30, 60 und 90 Tage nach der Behandlung der Saft extrahiert und auf Imidacloprid analysiert. Trockne Blattproben wurden 30 und 90 Tagen nach der Behandlung analysiert. Kombinierte Xylem- und Kambiumsaftproben aus 0,5 m und 1,0 m über der Injektionsstelle wurden 90 Tage nach der Behandlung auf Imidacloprid untersucht. Die Konzentrationen in Bäumen, die im Mai mit Pointer behandelt wurden, waren 7 Tage nach der Behandlung höher als die unbehandelten Kontrollbäume, aber sie waren nicht deutlich anders als die Kontrollen an den anderen Tagen oder differierten zu Imicid an irgendeinem Tag. Der Level von Imidacloprid im Saft von Bäumen, die Juli mit Pointer behandelt wurden, war 30 Tage nach der Behandlung deutlich höher als bei der Kontrolle, aber differierten nicht von Imicid. Der Level von Imidacloprid in trocknen Blättern bei mit Pointer behandelten Bäumen war 30 und 90 Tage nachher höher als mit der Imicid-Behandlung und den Kontrollbehandlungen. Der Level von Imidacloprid im Xylem und Kambium war bei Pointer höher als mit Imicid 90 Tage nach der Behandlung und einer Probenentnahme in 1,0 m Höhe, aber bei der Höhe 0,5 m gab es keine deutlichen Unterschiede. Bei Imicid-Behandlungen war kein Imidacloprid-Level deutlich anders als bei den unbehandelten Kontrollbäumen.

Resumen. Dos productos de inyección de imidacloprid al tronco (Pointer $^{\mathrm{TM}}$, ArborSystems; y Imicide ${ }^{\circledR}$, J.J. Mauget Co.) fueron aplicados a fresnos verdes (Fraxinus pennsylvanica Marsh.) en Mayo y Julio para comparar las concentraciones de imidacloprid en la savia y tejidos de la hoja y en el tronco después de las inyecciones. Se extrajeron muestras de savia de brotes $0,3,7,30,60$, y 90 días después del tratamiento y se analizaron para imidacloprid. Las muestras secas de las hojas fueron analizadas para imidacloprid 30 y 90 días después de los tratamientos. Muestras combinadas del xilema y zona cambial fueron analizadas para imidacloprid a 90 días después del tratamiento a $0.5 \mathrm{~m}(1.6 \mathrm{ft}$.) y $1.0 \mathrm{~m}(3.2 \mathrm{ft}$.) arriba de los sitios de inyección. Las concentraciones de imidacloprid en la savia en los árboles tratados en Mayo con Pointer fueron significativamente más altas que los controles no tratados, 7 días después de los tratamientos $(P<0.05)$, pero no fueron significativamente diferentes de Imicide. Los niveles de imidacloprid en la savia de los árboles tratados en Julio con Pointer fueron significativamente más altos que los controles 30 días después del tratamiento, pero no fueron significativamente diferentes de Imicide. Los niveles de imidacloprid en las hojas secas en los árboles tratados con Pointer fueron significativamente más altos que Imicide y los controles 30 y 90 días después del tratamiento. Los niveles de imidacloprid en el xilema y la zona cambial en los árboles tratados con Pointer fueron significativamente más altos que el Imicide y controles 90 días después del tratamiento a $1.0 \mathrm{~m}$ (3.2 ft.) arriba de los sitos de inyección, pero no fueron significativamente más altos a $0.5 \mathrm{~m}$ (1.6 $\mathrm{ft}$.). Los niveles de imidacloprid en Imicide no fueron significativamente diferentes de los árboles de control no tratados. 